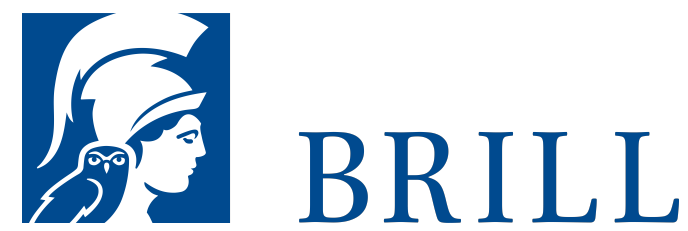

\title{
Über den Menschen als Kunstwerk
}

Zu einer Archäologie des (Post-)Humanen im Diskurs der

Moderne (1750-1820)

Author: Britta Herrmann

Seit der Aufklärung entwirft sich der Mensch als ein durch Technik, Wissenschaft und Kunst erst noch zu vollendendes Wesen. Welchen Anteil hat die Literatur an diesem Optimierungsprogramm?

Mit Blick auf zeitgenössische Überlegungen zur elektrischen und medialen Steuerung der Körperströme, auf Züchtungs- und Reproduktionsexperimente, prothetische Optimierungen und technische Körpersimulationen rekonstruiert Britta Herrmann die Geschichte der >Erfindung des Menschen $<$ im Verhältnis zwischen Naturforschung, Philosophie, technischen Entwicklungen und poetologisch-ästhetischen Diskursen. Bereits in der scheinbar humanistischen Aufklärung produziert das Optimierungsdenken posthumane Körper und Identitäten. Teil daran haben nicht zuletzt die ästhetischen Programme von Klassizismus und Romantik, welche spezifisch an der Hervorbringung des künftigen Menschen arbeiten und ihre Poetiken gezielt danach ausrichten.

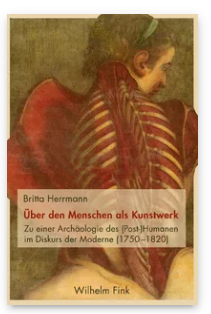

Pages: 568

Seiten

Language:

German

Subjects:

German,

Literature and

Cultural Studies

Publisher: Brill |

Fink

E-Book (PDF)

Released online:

18 Dec 2017

ISBN: $978-3^{-}$

$8467-5970-7$

List price

Paperback

Publication date:

15 Dec 2017

ISBN: 978-3-

7705-5970-1

List price 
For more information see brill.com

Order information: Order online at brill.com +44330 333 0049 | customerservices@brill.com Submission information: brill.com/authors

Titles published by Brill | Fink, Brill | mentis or Brill | Schöningh: +49(o)715413279216| brill@brocom.de 